\title{
Design and Development of Innovative Highland Water Filtration System
}

\author{
Mohd Hudzari Razali*, Syazili Roslan, Abdus Ssomad M. Abd Halim, \\ Ahmad Farizal Md. Shokeri, Nur Azuan Husin \\ Faculty of Bioresources \& Food Industry, Universiti Sultan Zainal Abidin, Tembila Campus, Malaysia \\ Email: *mohdhudzari@unisza.edu.my
}

Received 3 February 2016; accepted 31 July 2016; published 3 August 2016

Copyright (C) 2016 by authors and Scientific Research Publishing Inc.

This work is licensed under the Creative Commons Attribution International License (CC BY).

http://creativecommons.org/licenses/by/4.0/

c) (i) Open Access

\begin{abstract}
The righteous book of Al-Quran mentions that the basic need of the living thing in this world is water. Resident of rural areas such as indigenous people will tap the highland aquatic resources as the main foundation for water. The reservoir is built on the top of hilly area to collect water before it discharges through a pipe system that uses the force of gravity to go down to the settlements. However, the filtration system frequently clogs and requires the occupants to climb up the reservoir hill for cleaning process. A lot of energy and time are required to manage the irrigation systems. Thus, an innovation system has been conducted as the filters will be cleaned automatically using solar energy supply. The designs of the filters are specially designed as the filter is equipped with electric motors, washer rods, power supply units, and automatic control box. The advantages of this project are the product will filtered the water as remain as natural highland watering resources while using the solar energy to accomplished green technology application.
\end{abstract}

\section{Keywords}

Water Filtration, Clogging and Foreign Material, Solenoid Valve, Relay Automation, Solar Energy

\section{Introduction}

This study was focused toward to create a filtration system using new ideas in order to overcome the problem of clogged on filtering system. This project was used of solar energy as a power source to operate this filter system. Irrigation system is very important to people either for agricultural purposes or daily use. Clean water source can affect human health. Natural water resources include lakes, rivers, streams, groundwater, precipitation and

${ }^{*}$ Corresponding author.

How to cite this paper: Razali, M.H., Roslan, S., Halim, A.S.M.A., Shokeri, A.F.M. and Husin, N.A. (2016) Design and Development of Innovative Highland Water Filtration System. World Journal of Engineering and Technology, 4, 383-390. 
oceans. Water is a fundamental resource to all human [1]. This study focuses on the population in the rural area such as the aborigine. This is because they are use natural water for daily used. However, accesses to the water are limited and less efficient. A lot of energy and time are required to manage the operation of the natural water supply.

Many constrain needs to be faced by aborigine in order to get the water supply as the topography of the hilly terrain and steep slopes, attack by wildlife and unpredictable weather. Natural water resources should be shared with other users such as animal in the wild. Therefore proper planning should be done to ensure that it does not interfere with the existing ecosystem. To keep the existing ecosystem from damage, this creates filter that uses solar energy to operate. This is to prevent from air pollution cause by the smoke that is released when using gasoline or diesel engine to operate this device. Also it avoids from contamination, and the used of solar energy from nature can be reduce the operating costs, thus helping to increase the productivity. Solar energy will be collected and stored in the batteries for this device. Solar power is energy from the sun and without it is presence all life on earth would end. Solar energy has been locked upon as serious source of energy for many years because of the vast amounts of energy that are made freely available, if harnessed by modern technology. The amount of solar radiation at location receives depend on a variety of factors including geographic location, time of day, season, local landscape, and local weather. The discovery of photovoltaic's happened in 1839 when the French physicist Edmon Becquerel first showed photovoltaic's activity [2]. Edmon had found that electrical current in certain materials could be increased when exposed to light. Residents in rural areas need clean water sources for agricultural or daily use. However, topography and weather conditions often cause the quality of natural water resources become less favourable. For example, the water becomes cloudy when rain and reservoir water will produce a precipitate dirty and are filled with trash from environment such as leaves. Their rural area at remote site makes it difficult to get water and electricity resources. Good irrigation system is able to produce good quality of water [3]. However, the open reservoir system causes garbage collected from the environment that cause of a clogged filter. The results of clogged filter it cause the water flow become slow and disrupt the user. The garbage that attached to filter also becomes act as a host to breeding of maggots (Figure 1). Water from the dirty filter is also having adverse effect on consumers. Figure 2 shows the conventional filtering system. When the filter was clogged, the villagers had to climb a hill to clean the filter. It takes a long of time and a lot of manpower. The situation worsened during the rainy season because the more waste will be accumulated in reservoir. The used of solar systems require a particularly high cost to start-up and maintenance. This system requires maintenance when it is unable to collect the energy well. This system requires some basic things such as solar panel, solar charger controller, battery, and inverter. In addition, the solar systems require a knowledgeable operator and have skills to operate it.

This study produced a prototype of the filtration system that can solve the problem of filter clogged with debris. Thus, the system was capable to supplied clean water to consumers. The management cost of this system also can be reduced with the use of solar energy that can be obtained for free. Maximum use of natural resources such a hill water resources and sunlight can be reduced of management cost and protected by the environment from pollution [4]. Thus the life of the aborigines can be enhanced by the availability of a filter system that can be operate automatically according to a predetermined rate to wash sill the debris that accumulated on the filter. The management of time and energy can be maximized. In lively development of city, development in rural areas should be also not being forgotten in order to develop society and have a good quality of life.

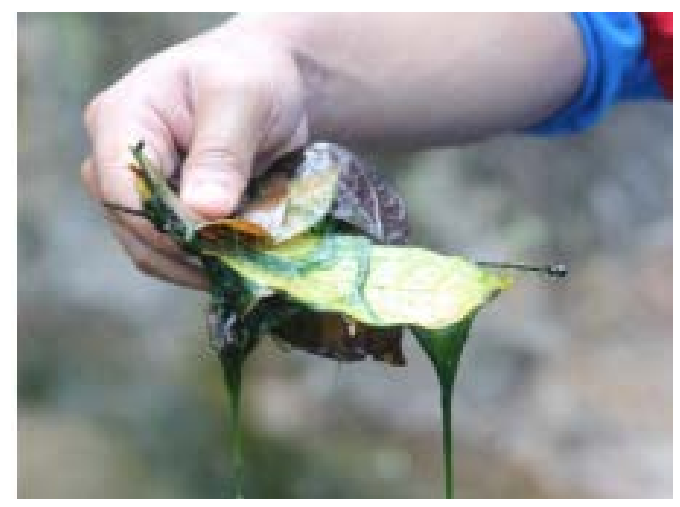

Figure 1. The garbage that attached to the filter. 


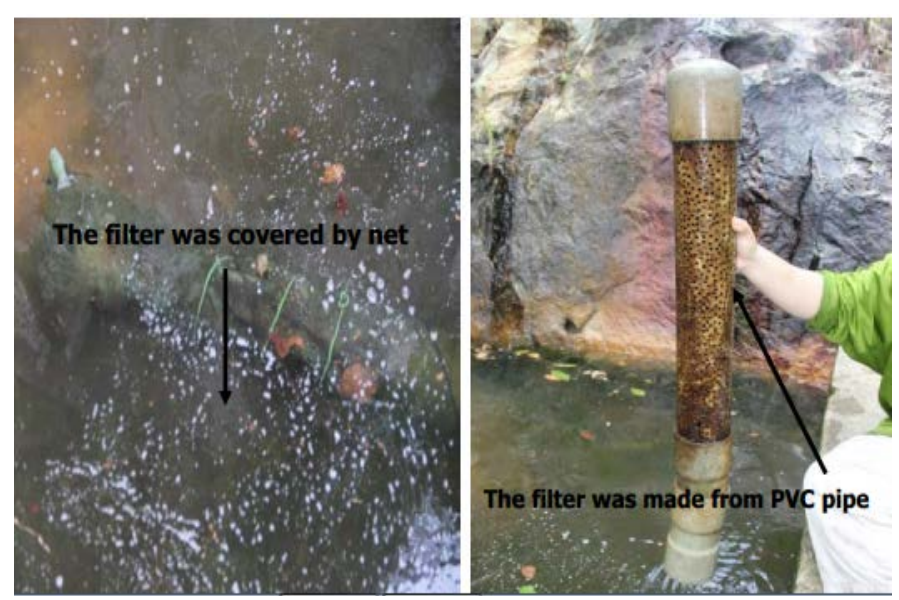

Figure 2. The conventional filtering system.

\section{Materials and Method}

\subsection{Preparation of Materials}

The materials needed for this study such as solar panel, battery, solar charger controller, wiper motor, multimeter, PVC pipe, PVC socket, drill, wire, plastic box, angle iron, nut and bolt, limit switch, timer, relay, fuse and connector block. All the materials were purchased from several hardware shops in Terengganu, Malaysia.

\subsection{Site Visit}

On October 3, 2013, a group of researchers from Universiti Sultan Zainal Abidin (Uni SZA) was visited to Kampung Baru, Tepoh, Terengganu to observe the irrigation system that used in the village. Based on the observation, this village are used the natural water sources. A reservoir (Figure 3) was built on hilltop to block the water before it is passed on to consumers by using metal pipe. The sized of reservoir is about $15 \mathrm{ft} \times 15 \mathrm{ft}$. The normal filter system was used and it made from PVC pipe. The size of filter is about $3 \mathrm{ft}$ long. On the outside of the filter was covered with layer netting. The problem is when the garbage stuck in the net and it cause clogging of filters. The reservoir consists of two parts of the outlet where the steel pipeline was delivers water to consumers and other one was allow overflow of water to drain out from the reservoir. Culinary water is not used in the pressurized irrigation system. As such, the pressurized irrigation water is not drinkable.

Residents should be taken the same precautions they would with any irrigation water that may contain bacteria regularly found $\mathrm{n}$ rivers and streams. The natural water need to be filtered depends upon its end use and how long the water will be stored. For simple water reservoir system that use gravity to supply a main pipe, an inlet screen that filters large leaf debris is all that is needed, provided the water is used within several weeks. Irrigation in the mountains is found in two distinct ecology zones such as valley bottom and highland slope. Along valley bottoms man communities construct flood control device to prevent rainy season inundation of their fields. Recent evidence also indicates at least one post-Columbian use a filtration in the highland. The importance of pre-filtering rainwater before it enters the storage container is often overlooked. Complaints of stored rainwater smelling or turning "rotten" can always be traced to improper pre-filtration. If rainwater is not pre-filtered, a large amount of organic matter I the form of leaves and dirt can enter the storage tank. Aerobic bacteria begin to consume the organic matter use up all the dissolved oxygen. Anaerobic bacteria begin to predominate resulting in odour. Other benefits of pre-filtering rainwater are reduced sediment build up at the bottom of the storage tank and less tank maintenance.

\subsection{Arc Welding}

Arc welding is a type of welding that uses welding power supply to create an electric arc between electrode and the base material to melt the metal at the welding point. They can use either direct (DC) or alternating (AC) current, and consumable or non-consumable electrode. The welding region is usually protected by some type of 


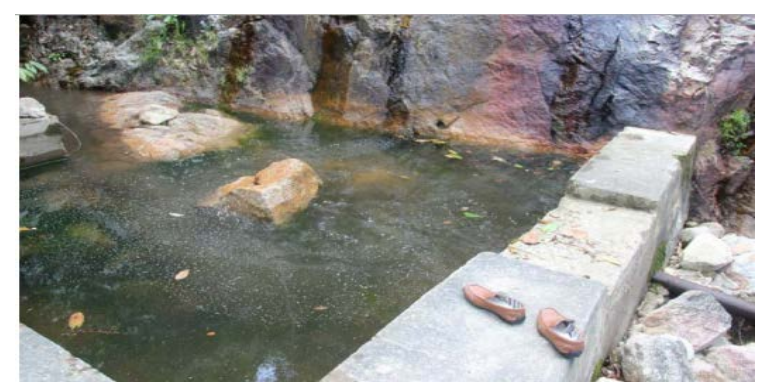

Figure 3. The reservoir.

shielding gas, vapour, or slag [5] [6]. Arc welding processes may be manual, semi-automatic, or fully automated. Figure 4 shows the arc welding machine.

Temperature distribution during any welding process holds the key for understanding and predicting several important welding attributes like heat affected zone, microstructure of the weld, residual stress, and distortion during welding. The accuracy of the analytical approaches for modelling temperature distribution during welding has been constrained by oversimplified assumptions regarding boundary conditions and material properties. The joining metal requires more than moving an electrode along a joint [7]. Metals at high temperatures tend to react chemically with elements in the air-oxygen and nitrogen. When metal in the molten pool comes into contact with the air, oxides, oxides and nitrides from which destroy strength and toughness of the weld joint. Therefore, many arc-welding processes provide some means of covering the arc and the molten pool with a protective shield of gas, vapour, or slag. This is called arc shielding. This shielding also may improve the weld. An example is a granular flux, which actually adds deoxidizers to the weld. The operation variable affecting the mode of metal transfer are the welding current, composition of shielding gas, extension of electrode beyond the current contact tube, ambient pressure, active element coatings on the electrode, polarity and welding material. Among these variables, welding current is the most common variable that the welder adjusts to obtain the desired metal transfer mode. At low welding currents, globular transfers' mode occurs, while spray transfer mode occurs at relatively higher welding currents [8].

\subsection{Process of Building the Prototype}

Rough sketch of the design of the filter was made to get a clearer view. The materials prepared according to the size needed such as Angle iron $37 \mathrm{~cm}=2$ units, Angle iron $47.5 \mathrm{~cm}=2$ nits, Flat iron $33 \mathrm{~cm}=1$ unit, Flat iron 6 $\mathrm{cm}=2$ unit, PVC pipe $60 \mathrm{~cm}=1$ unit and Rod iron $37 \mathrm{~cm}=1$ unit. Assembling of each part should be done carefully and thoroughly. The assembling process was made by using arc-welding techniques. Proper technique should be used to ensure the high quality of results. Precaution measures should be taken to avoid any accident. After completed the assembling process of basic frame, the electronic circuit control box was constructed in accordance with the desired control system. The basic sketch of the system must be checking first to ease of installation equipment needed. Installation of equipment for builds an electronic circuit controller box according to the sketch that was made. Test the prototype that has been built. Tests are done to check whether the prototype is able to work or not. Proficiency testing also done to see the capability of this prototype.

\subsection{Solid Software}

Solidworks refers to a 3D computer aided design program that enables to transform new ideas into great products. Its runs on a Microsoft platform and is mainly used by engineers and designers all over the world. From this study, Solidworks is used to design a water filter. Figure 5 shows the technical drawing using the "Solidwork Software” and Figure 6 shows the multi-dimensional drawings.

\section{Results and Discussion}

The experiments that have been done to create a prototypes of innovative filtering system for highland irrigation and measuring the effectiveness of that device for 20, 40, 60, 80, 100, and 120 minutes. This filter was used to overcome the clogged problem which it faced by rural people. As we know, the filters are submerged in the water 


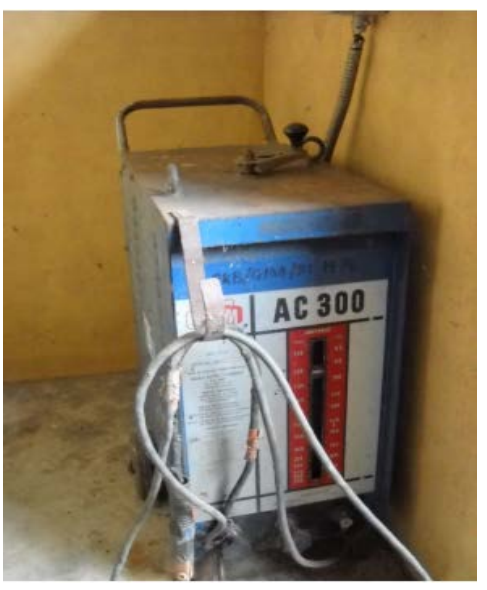

Figure 4. The arc welding machine.

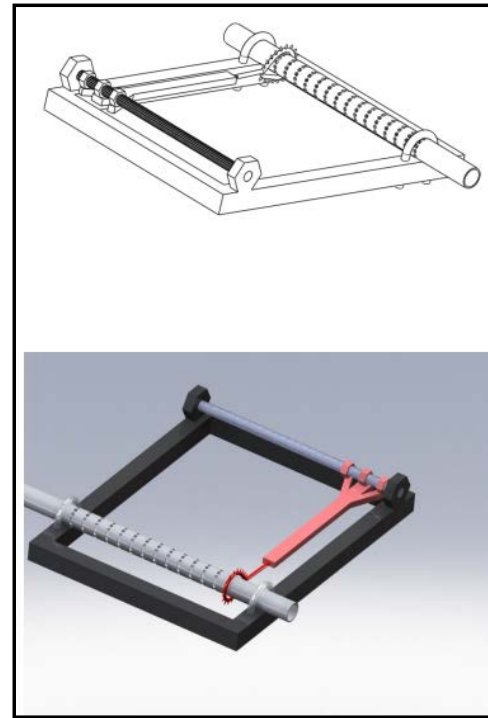

Figure 5. The technical drawing by using "Solidwork Software".

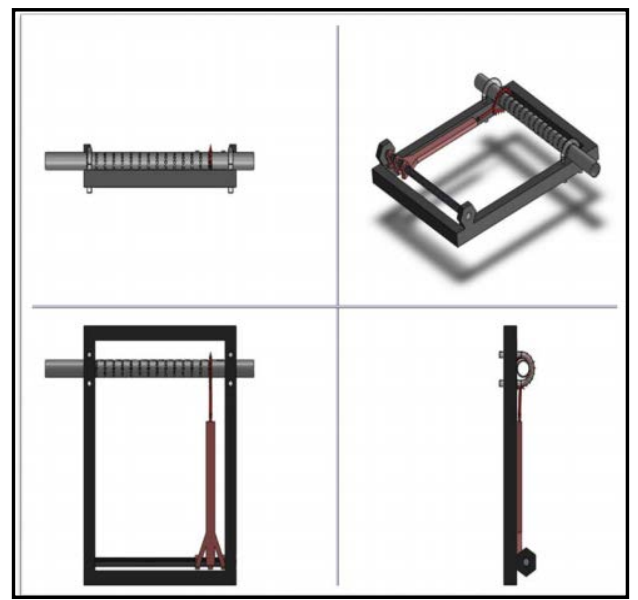

Figure 6. The multi-dimensional drawings by using "Solidwork Software". 
for the long periods of time will be because it clogged by foreign object such as moss, leaves and twigs. The factors of emphasis in this prototype were welding techniques, welding safety and effectiveness of the prototype during this work.

\subsection{Limit Switch}

The limit switch (Figure 7) is a switch operated by the motion of a machine part presence of an object. They are used for control of a machine, as safety interlocks, or to count objects passing a point. A limit switch is an electromechanical device that consists of an actuator, mechanically linked to set of contacts. When an object comes into contact with the actuator, the device operates the contact to make or break an electrical connection. In this project, the limit switch was used as a benchmark to show the maximum movement of washer rod which it move through the rod and it acts as a key to control the movement of the washers rod to complete the movement (point A—point B-point A).

\subsection{Solar Panel}

The solar panel used (Figure 8) in this project was polycrystalline and it has a maximum system voltage of 600 $\mathrm{V}$ and a maximum power of 87 watts. This solar pane are produced from several types of liquid crystals where it put into moulds and frozen with CVD process "chemical vapour deposition" [9]. It is easily to known by some combination of properties such as we can see it like an abstract of broken glass crystal. The energy collected from the sun was stored in the battery. Therefore, this system requires solar charger controller for automatically controlling the charging process with it able to cut off the excessive current if the battery has been fully charged. The $12 \mathrm{~V}$-capacity batteries were use in this project.

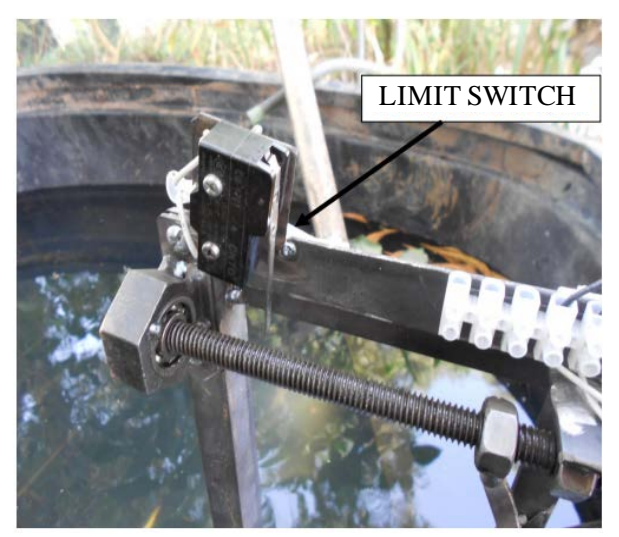

Figure 7. The limit switch used.

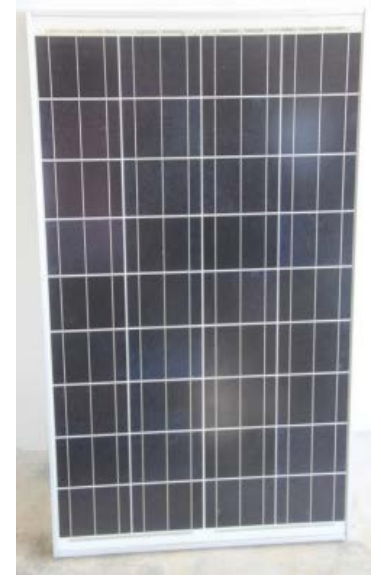

Figure 8. The solar panel used. 


\subsection{Motor Wiper}

The DC motor used to drive this system is the rear windshield wiper motor [10]. Figure 9 shows the image of the motor used.

The wiper motor ability tests was conducted to determine the appropriate amount of time for it to work well for this prototype. Tests are done for the past 20, 40, 60, 80, 100, and 120 minutes. The result of these tests shows in Table 1.

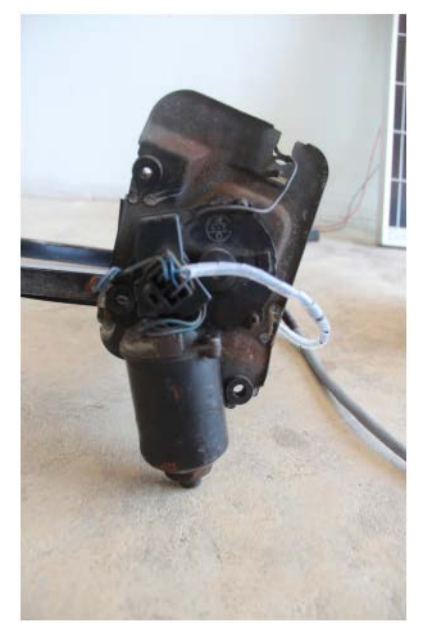

Figure 9. The motor wiper used.

Table 1. The result of motor wiper ability test.

\begin{tabular}{ll} 
TIME & DESCRIPTION \\
(MINUTES) & (DEVICE FUNCTIONALITY) \\
\hline 20 & 1) The motor functions well without any problems \\
2) The washer rod moves perfectly \\
1) The motor functions well without any problems \\
2) The washer rod moves perfectly \\
1) The temperature of motor was increase \\
2) The washer rod moves perfectly \\
80 & 1) The temperature of motor was too high \\
& 2) The washer rod moves with a small vibrating \\
100 & 1) The temperature of motor was too high and it loss of power \\
& 2) The washer rod moves slowly with high vibrating \\
& 1) The temperature of motor was too high and it loss of power \\
& 2) The washer rod failure to function.
\end{tabular}

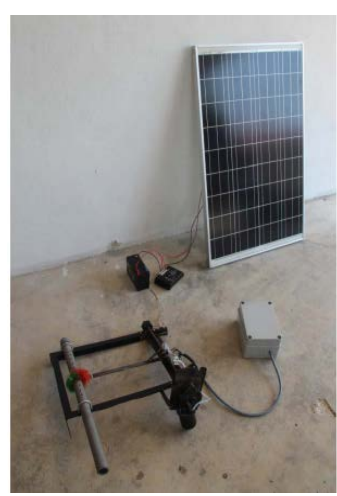

Figure 10. The complete set of automatic filtering system. 


\section{Conclusion}

After research, we find that this developed filter still has some weakness with the operation timing. As proposed, the improvement can be done by changing the use of a timer system to sensor system. Sensor system is more effective than the timer system as it will operate only on the time required. Moreover, the addition of water jet nozzles can also be installing on the main rod to increase cleaning effectiveness rate. Figure 10 shows the complete set of automatic filtering system.

\section{References}

[1] Ali, A., Al-Soud, M., Abdallah, E. and Addallah, S. (2009) Water Pumping System PLC and Frequency Control. Jordan Journal of Mechanical and Industrial Engineering, 3, 216-221.

[2] Bagnall, D.M. and Borelan, M. (2008) Photovoltaic Technologies. Energy Policy, 36, 4390-4396.

[3] Farukdurdu, O. (2010) Fuzzy Logic Adaptive Kalman Filtering in the Control of Irrigation Canals. International Journal for Numerical Methods in Fluids, 64, 187-208.

[4] Abdallah, S. and Abdulkarim, A. (2004) Methodology to Design an Automated Pump Plaint with PLC Control System. Proceedings of the International Engineering Conference, 373-398.

[5] Kucukoglu, G. and Mlaoney, L. (2008) Interactions between Surface Material and Perception of Angular Velocity of Rotating 3D Objects. Journal of Vision, 13, 67.

[6] Murphy, A.B. (2006) The Effects of Metal Vapour in Arc Welding. Journal of Physics D: Applied Physics, 43, Article ID: 434001

[7] Paskell, T., Lundin, C. and Castner, H. (1997) GTAW Flux Increase Weld Joint Penetration. Welding Journal, 76, 5762.

[8] Gery, D., Long, H. and Maropoulos, P. (2005) Effects of Welding Speed, Energy Input and Heat Source Distribution On Temperature Variations in Butt Join Welding. Processing Technology, 167, 393-401.

[9] Granqvist, C.G. (2004) Materials for Solar Energy, Encyclopedia of Energy. Vol 3, Elsevier, New York.

[10] Auinger, H. and Siemens, AG. (2001) Efficiency of Electric Motors under Practical Conditions. Power Engineering Journal, 15, 163-167.

\section{Submit or recommend next manuscript to SCIRP and we will provide best service for you:}

Accepting pre-submission inquiries through Email, Facebook, Linkedin, Twitter, etc A wide selection of journals (inclusive of 9 subjects, more than 200 journals)

Providing a 24-hour high-quality service

User-friendly online submission system

Fair and swift peer-review system

Efficient typesetting and proofreading procedure

Display of the result of downloads and visits, as well as the number of cited articles

Maximum dissemination of your research work

Submit your manuscript at: http://papersubmission.scirp.org/ 